\section{A review of the evidence for and against the use of steroids in renal transplant patients with COVID-19}

\author{
Nouf E. AL-Otaibi, Pharm.D, BCPS.
}

$\mathrm{C}^{\mathrm{o}}$ oronavirus disease 2019 (COVID-19) is caused by a novel coronavirus called severe acute respiratory syndrome coronavirus 2 (SARS-CoV-2), which was primarily recognized as a flare-up of respiratory illness ranging from mild to severe cases in China in December 2019.

According to the Centers for Disease Control and Prevention (CDC), ${ }^{1}$ COVID-19 poses a high risk to renal transplant recipients due to the immunosuppressed state induced by transplant medications. Common symptoms in renal transplant patients with COVID-19 are fever, diarrhea, and respiratory symptoms.

Renal transplant patients infected with COVID-19 have a higher risk of 30-day mortality than nontransplant patients (17.9\% versus $11.4 \%$, according to one study). ${ }^{2}$ Another study showed an overall mortality rate of $20 \%$ in organ transplant patients versus $4-14 \%$ mortality in non-transplant COVID-19 patients. $^{3}$

There have been limited reports on graft rejection in renal transplant recipients who received a diagnosis of COVID-19. However, one case report described a 56-year-old patient who experienced antibodymediated rejection 4 weeks after COVID-19 infection. ${ }^{4}$ An examination revealed sphere-shaped spiked units in the glomerular capillary indicative of an established COVID-19 infection within the kidneys.

Multiple recommendations and guidelines have suggested discontinuing calcineurin inhibitors, including tacrolimus and cyclosporin, in transplant patients infected with coronavirus. ${ }^{5}$

On the other hand, growing evidence suggests that severe COVID-19 leads to mortality due to cytokine storm syndrome. ${ }^{6}$ Thus, immunosuppressive medications may have a good effect on transplant patients with COVID-19.

Keywords: renal transplant, COVID-19, steroids, Corona virus

Saudi Med J 2021; Vol. 42 (10): 1149-1152 doi: 10.15537/smj.2021.42.10.20210551
Corticosteroids are a keystone of many immunosuppressive regimens, including induction therapy, maintenance immunosuppressive therapy, and treatment of graft rejection; however, their use in COVID-19 is controversial.

The purpose of this review is to study the available evidence and guidelines regarding the use of corticosteroids in kidney transplant recipients infected with COVID-19 and to assess the evidence for and against their use in such patients.

A review of English-language articles was carried out using Scopus, PubMed from January 1st, 2020 to July 31st, 2021. Keywords included COVID-19, renal transplant, steroids, corticosteroids, immunosuppression and, Coronavirus. The search resulted in 15 articles most of which were case reports and case series.

Corticosteroids have been a cornerstone of many renal transplant protocols since the 1960 s. $^{7}$ They play a vital role in all phases of transplantation, including induction therapy, maintenance immunosuppressive therapy, and treatment of graft rejection. However, the widespread use of steroids has drawbacks, including metabolic complications, cosmetic changes, cardiovascular events, and deleterious effects on pediatrics growth. Thus, some healthcare centres have adopted steroid-free or steroidminimal protocols, especially for pediatrics patients. ${ }^{7}$

Evidence supporting the continued use of steroids in renal transplant patients with COVID-19. Generally, the approach to managing acute COVID-19 in renal transplant recipients is similar to that in non-renaltransplant patients. Many solid organ transplant experts maintain or increase corticosteroid dosage in cases of COVID-19 infection. This practice is supported by many studies, ${ }^{8-11}$ including the following: RECOVERY is a multi-center, randomized clinical trial conducted on hospitalized patients with suspected or confirmed COVID-19 that included more than 6,000 patients who received systemic steroid treatment with dexamethasone for 10 days or until discharge. This patient population did not include renal transplant patients, but the outcome was in favor of using steroids. The dexamethasone group showed a lower mortality rate and yielded a great benefit for those on mechanical ventilation. Data from a meta-analysis of 7 randomized trials showed reduced mortality among critically ill COVID-19 patients who received steroid treatment.

Disclosure. Author have no conflict of interests, and the work was not supported or funded by any drug company. 
Similar outcomes were observed in Metcovid and CoDEX trials.

Infectious Diseases Society of America guidelines suggest using steroids to treat patients hospitalized with severe COVID-19, including those with an oxygen saturation level under $94 \%$ on room air and those admitted to the ICU mechanical ventilation or for treatment for septic shock or extracorporeal membrane oxygenation. ${ }^{12}$

Table 1 shows studies in which steroids were used to treat renal transplant patients with COVID-19, the majority of which showed positive outcomes.

Table 1 - Cases of kidney transplantation patients infected with Corona virus-19 on steroidal therapy

\begin{tabular}{|c|c|c|c|c|c|c|c|c|}
\hline $\begin{array}{l}\text { Type of } \\
\text { study/Ref }\end{array}$ & $\begin{array}{c}\text { Age } \\
(\mathrm{y})\end{array}$ & $\mathrm{N}$ & G & $\begin{array}{c}\text { Time from } \\
\text { transplantation } \\
(\mathrm{y})\end{array}$ & Maintenance IS & $\begin{array}{l}\text { Continued } \\
\text { steroid? }\end{array}$ & Setting & Outcomes \\
\hline Cohort trial $^{5}$ & $\begin{array}{l}51- \\
64\end{array}$ & 20 & $\mathrm{M}$ & Median 13 & $\begin{array}{l}\text { Withdrawn all IS } \\
\text { started on methylpred } 16 \mathrm{mg}\end{array}$ & Yes & $\begin{array}{l}6 \text { mild hospitalized } \\
10 \text { severe, } 4 \text { critical } \\
\text { (ICU) }\end{array}$ & $\begin{array}{l}6 \text { patients developed AKI } \\
5 \text { patients died }\end{array}$ \\
\hline Case report ${ }^{13}$ & 65 & 1 & M & Unknown & TAC, MMF, Pred & Yes & Severe ICU & Recovery after 10 days \\
\hline \multirow[t]{8}{*}{ Case series ${ }^{14}$} & 21 & 8 & $\mathrm{~F}$ & 0.3 & TAC, Pred & Yes & Inpatient & $\begin{array}{l}\text { Recovery Discharged after } 2 \\
\text { days }\end{array}$ \\
\hline & 71 & & M & 3 & TAC, Pred & Yes & Inpatient & $\begin{array}{l}\text { Discharged after } 2 \text { days with } \\
\text { stable kidney function }\end{array}$ \\
\hline & 50 & & M & 0.2 & TAC reduced dose, Pred & Yes & Self-isolation & Full recovery \\
\hline & 63 & & M & 15 & TAC, Pred & Yes & Inpatient & Recovery discharged after 7 days \\
\hline & 47 & & $\mathrm{~F}$ & 0.4 & TAC, Pred & Yes & Severe ICU & $\begin{array}{l}\text { AKI recovery, discharged after } \\
21 \text { days }\end{array}$ \\
\hline & 71 & & $\mathrm{~F}$ & 15 & TAC, Pred & Yes & Inpatient & Discharged after 4 days with full \\
\hline & 40 & & $\mathrm{~F}$ & 3 & & & & recovery \\
\hline & 38 & & M & 6 & TAC reduced dose, Pred & Yes & & Discharged after 2 days \\
\hline $\begin{array}{l}\text { Systematic } \\
\text { review }^{15}\end{array}$ & $\begin{array}{l}31- \\
75\end{array}$ & 554 & $\stackrel{\mathrm{M}}{\mathrm{F}}$ & Range: $0-25$ & $\begin{array}{l}\text { CNI: withdrawn in } 31.9 \% \text {, } \\
\text { reduced in } 19.7 \% \\
\text { AD: withdrawn in } 75.3 \% \text {, } \\
\text { reduced in } 9.5 \% \\
72 \% \text { were on Pred }\end{array}$ & Yes & $\begin{array}{l}\text { Ranging from } \\
\text { home isolation to } \\
\text { ICU admission }\end{array}$ & $\begin{array}{l}\text { Renal graft function remained } \\
\text { stable in } 76.17 \% \text { of patients, } \\
\text { whereas } 8.84 \% \text { experienced graft } \\
\text { loss and } 1.44 \% \text { developed AKI. } \\
21.84 \% \text { of patients died }\end{array}$ \\
\hline Case report ${ }^{16}$ & 29 & 1 & M & 1.2 & $\begin{array}{l}\text { Cyclosporin, MMF, } \\
\text { methylpred }\end{array}$ & Yes & Inpatient & Recovery after 13 days \\
\hline Case report ${ }^{17}$ & 61 & 1 & $\mathrm{~F}$ & 16 & MMF, Pred & Yes & Inpatient & Recovery after 5 days \\
\hline Case report ${ }^{18}$ & 52 & 1 & M & 12 & $\begin{array}{l}\text { D/C all IS. Started on } \\
\text { methylpred } 40 \mathrm{mg}\end{array}$ & Yes & Inpatient & Recovery discharge after 13 days \\
\hline Case report ${ }^{19}$ & 50 & 1 & M & 4 & $\begin{array}{l}\text { Pred continued TAC and } \\
\text { everolimus withdrawn }\end{array}$ & Yes & ICU & Still in ICU at time of report \\
\hline \multirow[t]{2}{*}{ Case report ${ }^{20}$} & 75 & 2 & M & 10 & TAC, MMF: D/C Pred & Yes & Severe inpatient & Died after 5 days \\
\hline & 52 & & $\mathrm{~F}$ & 0.8 & & & & AKI discharge on day 14 \\
\hline Case report ${ }^{21}$ & 58 & 1 & M & 11 & MMF and steroid & Yes & Severe ICU & $\begin{array}{l}\text { Died with multiorgan } \\
\text { dysfunction }\end{array}$ \\
\hline Case report ${ }^{22}$ & 32 & 1 & M & 2 & $\begin{array}{l}\text { MMF, increased dose Pred, } \\
\text { TAC }\end{array}$ & Yes & Inpatient & AKI resolution and discharge \\
\hline Case report ${ }^{23}$ & 28 & 1 & $\mathrm{~F}$ & 0.5 & MMF, TAC, Pred & Yes & Mild inpatient & Discharged with full recovery \\
\hline Case report ${ }^{24}$ & 54 & 1 & M & 5 & $\begin{array}{l}\text { DC TAC, Pred, EVE, } \\
\text { continued on methypred } 40 \\
\text { mg IV daily }\end{array}$ & Yes & Severe ICU & Discharged after 49 days \\
\hline $\begin{array}{l}\text { Systematic } \\
\text { review }^{25}\end{array}$ & $\begin{array}{l}21- \\
80\end{array}$ & 561 & $\underset{\mathrm{F}}{\mathrm{M}}$ & $0-31$ & $\begin{array}{l}\text { Outcome } n=144: 84 \text { patients } \\
\text { increase steroid dose, } 6 \\
\text { patients either reduced or } \\
\text { DC, } 45 \text { patients with no } \\
\text { change }\end{array}$ & Variable & $\begin{array}{c}73 \text { severe inpatients } \\
40 \mathrm{ICU}\end{array}$ & $\begin{array}{l}\text { Outcome reported for } 144 \\
\text { patients: } 74 \text { patients discharged } \\
36 \text { improved still in hospital, } \\
34 \text { died }\end{array}$ \\
\hline $\begin{array}{l}\text { Cohort } \\
\text { study }\end{array}$ & $\begin{array}{r}53.8 \\
\pm 13.5\end{array}$ & 38 & $\stackrel{\mathrm{M}}{\mathrm{F}}$ & Median 5.8 & $\begin{array}{l}84.2 \% \text { on TAC, } 89.5 \% \\
\text { on MMF, } 81.6 \% \text { on Pred. } \\
\text { Adjunct steroid boluses were } \\
\text { provided for ARDS }\end{array}$ & Yes & $\begin{array}{l}38 \text { hospitalized: } 20 \\
\text { severe ICU }\end{array}$ & $\begin{array}{l}27 \text { patients survived } \\
11 \text { patients died }\end{array}$ \\
\hline TAC: Tacro & s, & 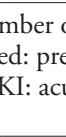 & & $\begin{array}{l}\text { s, G: gende } \\
\text { e, CNI: calc }\end{array}$ & $\begin{array}{l}\text { male, F: female, IS: immun } \\
\text { urin inhibitors either tacrolim } \\
\text { iscontinued, methylpred: } \mathrm{m} \\
\text { syndrome, IV: intr }\end{array}$ & $\begin{array}{l}\text { oression } \\
\text { cyclos } \\
\text { prednis }\end{array}$ & $\begin{array}{l}\text { J: intensive care unit } \\
\text { AD: antimetabolite } \\
\text { EVE: everolimus, } A\end{array}$ & $\begin{array}{l}\text { t, MMF: mycophenolate mofetil, } \\
\text { e drugs including mycophenolate } \\
\text { ARDS: acute respiratory distress }\end{array}$ \\
\hline
\end{tabular}


Saudi Ministry of Health Protocol for suspected or confirmed COVID-19 cases. The National Saudi Guidelines for managing COVID-19 infection support the use of steroids in patients infected with COVID-19, ranging from the use of inhaled budesonide in cases of new cough onset to the administration of systemic dexamethasone in severe cases requiring supplemental oxygen.

The National Institutes of Health COVID-19 Treatment Guidelines recommended treating renal transplant patients infected with COVID-19 in exactly the same way as non-transplant patients when it comes to the use of dexamethasone; however, they pay more attention to the use of tocilizumab with dexamethasone because both exhibit immunosuppressive effects and expose the patients to a risk of secondary infections. ${ }^{24}$

British guidelines on the management of transplant recipients diagnosed with or suspected of having COVID-19 suggest using a high dose of steroids to treat progressive pulmonary disease, and maintaining steroid dosage in cases of otherwise mild disease without increasing it. ${ }^{25}$

Evidence against using steroids (evidence for use of a steroid-sparing regimen) in COVID-19 patients. Data from a case report shows that a patient was treated successfully with a steroid-free regimen and a slight reduction in the dosage of other maintenance immunosuppression medications. ${ }^{26}$ The authors explain that steroid use may hinder immunity, diminish virus clearance, and intensify coronavirus shedding. However, the available evidence shows that the benefits of steroid use outweigh the risks.

In conclusion steroids are recommended to treat severe COVID-19 symptoms in renal transplant recipients at increased risk for contracting COVID-19 and for developing severe COVID-19 due to their immunocompromised state, especially those who require mechanical ventilation or supplemental oxygenation. On the other hand, steroid use is discouraged in patients with mild COVID-19 who do not require oxygen therapy. All patients who require steroid therapy should be monitored during steroid treatment for side effects, including hyperglycemia and secondary infections.

Protocols for optimal maintenance of immunosuppressive therapy in renal transplantation have not been fully established. The maintenance of immunosuppression medications during COVID-19 infection is frequently modified by either stopping or reducing antimetabolite use followed by the use of calcineurin inhibitors and maintenance of a steroid dose; however, the benefits associated with the reduction of immunosuppression medications must be carefully weighed against the risk of graft rejection.

Acknowledgment. The authors gratefully acknowledge Scribendi (www.editage.com) for the English language editing.

Received 7th July 2021. Accepted 24th August 2021.

From the Clinical Pharmacy Department, Umm Al Qura University, College of Pharmacy, Makkah, Kingdom of Saudi Arabia.

Addressed correspondence to: Dr. Nouf E. AL-Otaibi, Clinical Pharmacist Consultant of Solid Organ Transplant, Assistant Professor, Umm Al Qura University, College of Pharmacy, Makkah, Kingdom of Saudi Arabia. E-mail: nealotaibi@uqu.edu.sa

ORCID ID: https://orcid.org/0000-0001-7029-3089

\section{References}

1. Centers for Disease Control and Prevention. Groups at higher risk for severe illness. [Cited 2021 June 26]. Available from: https://www.cdc.gov/coronavirus/2019-ncov/need-extraprecautions/groups-at-higher-risk.html

2. Caillard S, Chavarot N, Francois H, Matignon M, Greze C, Kamar N, et al. Is COVID-19 infection more severe in kidney transplant recipients? Am J Transplant 2021; 21: 1295-1303.

3. Alfishawy M, Elbendary A, Mohamed M, Nassar M. COVID-19 Mortality in transplant recipients. Int J Organ Transplant Med 2020; 11: 145-162.

4. Anandh U, Gowrishankar S, Sharma A, Salama A, Dasgupta I. Kidney transplant dysfunction in a patient with COVID - 19 infection: role of concurrent Sars-Cov 2 nephropathy, chronic rejection and vitamin C-mediated hyperoxalosis: case report. BMC Nephrol 2021; 22: 128-229

5. Alberici F, Delbarba E, Manenti C, Econimo L, Valerio F, Pola A, et al. Management of patients on dialysis and with kidney transplantation during the SARS-CoV-2 (COVID-19) Pandemic in Brescia Italy. Kidney Int Rep 2020; 5: 580-585.

6. Mehta P, McAuley DF, Brown M, Sanchez E, Tattersall RS, Manson JJ. HLH Across Specialty Collaboration, UK. COVID-19: consider cytokine storm syndromes and immunosuppression. Lancet 2020 Mar 28; 395: 1033-1034.

7. Aref A, Sharma A, Halawa A. Does steroid-free immunosuppression improve the outcome in kidney transplant recipients compared to conventional protocols? World J Transplant 2021; 11: 99-113.

8. NasrAllah MM, Osman NA, Elalfy M, Malvezzi P, Rostaing L. Transplantation in the era of the Covid-19 pandemic: How should transplant patients and programs be handled? Rev Med Virol 2021; 31: 1-9.

9. Horby P, Lim WS, Emberson JR, Mafham M, Bell JL, Linsell $\mathrm{L}$, et al. RECOVERY collaborative group. Dexamethasone in hospitalized patients with Covid-19. N Engl J Med 2021 25; 384: 693-704.

10. Sterne JAC, Murthy S, Diaz JV, Slutsky AS, Villar J, Angus DC, et al. WHO Rapid Evidence Appraisal for COVID-19 Therapies (REACT) Working Group. Association between administration of systemic corticosteroids and mortality among critically ill patients with COVID-19: A meta-analysis. JAMA 2020; 324: 1330-1341. 
11. Jeronimo CMP, Farias MEL, Val FFA, Sampaio VS, Alexandre MAA, Melo GC, et al. Metcovid team. Methylprednisolone as adjunctive Therapy for patients hospitalized with coronavirus disease 2019 (COVID-19; Metcovid): A randomized, doubleblind, phase IIb, placebo-controlled trial. Clin Infect Dis 2021; 72: e373-e381.

12. Bhimraj A, Morgan RL, Shumaker AH, Lavergne V, Baden L, Cheng VC, et al. Infectious Diseases Society of America Guidelines on the Treatment and Management of Patients with COVID-19. Infectious Diseases Society of America 2021; Version 5.1.2. [Updated 2021 June 25; Cited 2021 July 1st]. Available from: https://libguides.logan.edu/citation_styles/nlm

13. Boparai S, Thurlapati A, Hansra R. COVID-19 and immunosuppression: a case of COVID-19 in a renal transplant recipient. Chest 2020; 158: A2387.

14. Elhadedy MA, Marie Y, Halawa A. COVID-19 in renal transplant recipients: case series and a brief review of current evidence. Nephron 2021; 145: 192-198.

15. Angelico R, Blasi F, Manzia TM, Toti L, Tisone G, Cacciola R. The management of immunosuppression in kidney transplant recipients with COVID-19 disease: An update and systematic review of the literature. Medicina (Kaunas) 2021; 57: 435.

16. Ning L, Liu L, Li W, Liu H, Wang J, Yao Z, et al. Novel coronavirus (SARS-CoV-2) infection in a renal transplant recipient: Case report. Am J Transplant 2020; 20: 1864-1868.

17. Adapa S, Konala V, Naramala S, Daggubati S, Koduri N, Gayam V, et al. COVID-19 in renal transplant patient presenting with active typical symptoms and resolved atypical symptoms. J Investig Med High Impact Case Rep 2020; 8: 2324709620949307.

18. Zhu L, Xu X, Ma K, Yang J, Guan H, Chen S, et al. Successful recovery of COVID-19 pneumonia in a renal transplant recipient with long-term immunosuppression. Am J Transplant 2020; 20: 1859-1863.

19. Guillen E, Pineiro GJ, Revuelta I, Rodriguez D, Bodro M, Moreno A, et al. Case report of COVID-19 in a kidney transplant recipient: Does immunosuppression alter the clinical presentation? Am J Transplant 2020; 20: 1875-1878.

20. Gandolfini I, Delsante M, Fiaccadori E, Zaza G, Manenti L, Degli Antoni A, et al. COVID-19 in kidney transplant recipients. Am J Transplant 2020; 20: 1941-1943.
21. Huang J, Lin H, Wu Y, Fang Y, Kumar R, Chen G, et al. COVID-19 in posttransplant patients-report of 2 cases. Am J Transplant 2020; 20: 1879-1881.

22. Bussalino E, De MariaA, Russo R, PaolettiE. Immunosuppressive therapy maintenance in a kidney transplant recipient with SARS-CoV-2 pneumonia: A case report. Am J Transplant 2020; 20: 1922-1924.

23. Arpali E, Akyollu B, Yelken B, Tekin S, Turkmen A, Kocak B. Case report: A kidney transplant patient with mild COVID-19. Transpl Infect Dis 2020; 22: e13296.

24. Rosa-Guerrero P, Trujillo-Aguilera A, Molina J, Navas A, LópezMartín C, Jurado A, et al. Case Report: Successful response to intravenous immunoglobulin and steroid pulses in a renal transplant recipient with severe Covid-19 disease and associated acute allograft failure. Front Immunol 2021; 12: 671013.

25. Hasan I, Rashid T, Suliman S, Amer H, Chirila R, Mai M, et al. Predictors of disease severity and outcome of hospitalized renal transplant recipients with COVID-19 infection: a systematic review of a globally representative sample. Rom J Intern Med 2021; 59: 10-42.

26. Santeusanio AD, Menon MC, Liu C, Bhansali A, Patel $\mathrm{N}$, Mahir F, et al. Influence of patient characteristics and immunosuppressant management on mortality in kidney transplant recipients hospitalized with coronavirus disease 2019 (COVID-19). Clin Transplant 2021; 35: e14221.

27. COVID-19 Treatment Guidelines Panel. Coronavirus Disease 2019 (COVID-19) Treatment Guidelines. National Institutes of Health. [Cited 2021 July 1st]. Available from: https://www. covid19treatmentguidelines.nih.gov

28. British Transplantation Society. Guidance on the Management of Transplant Recipients Diagnosed with or Suspected of having COVID19. [Updated 22nd January 2021. 2021 July 1]. Available from: https://bts.org.uk/wp-content/ uploads/2020/04/Clinical-management-of-transplants-andimmunosuppression-updated-24th-April-FINAL.pdf

29. Johnson KM, Belfer JJ, Peterson GR, Boelkins MR, Dumkow LE. Managing COVID-19 in renal transplant recipients: a review of recent literature and case supporting corticosteroid sparing immunosuppression. Pharmacotherapy 2020; 40: 517-524. 